\title{
Sustainability Development Environment: Improving Social Economy in Kalikondang Village, Demak Regency
}

\author{
S Sunarti*, Nany Yuliastuti, Lala Arastya Dewi, Bellia Putri Sari \\ Department of Urban and Regional Planning, Faculty of Engineering, Universitas Diponegoro, \\ Semarang, Indonesia
}

\begin{abstract}
Success in upgrading slums over time will tend to return to slums. This is due to unrelated economic, social, and environmental aspects. The newly upgraded Kalikondang Village tends to experience this problem because the economic sector does not support sustainability. Based on these problems, the purpose of this study is to find a sustainable model for settlement development and maintenance in Kalikondang Village, Demak Regency. The research method uses a mixed-method with a concurrent embedded model. Quantitative and qualitative descriptive analysis techniques by combining two existing forms of data with the literature. The results showed that the model of a sustainable development environment in the village of Kalikondang was to increase the economic sector first with new business dwellers, supported by increased institutional capacity at the community level as business managers. Both sectors will result in an increased income of citizens, so they can be managed by institutions in the community for sustainable development and environmental preservation. The research contribution is a model of the form of economic, social, and environmental sector relations which is the development of the theory of sustainable housing.
\end{abstract}

Keywords. environment, upgrading, slum, sustainable housing

\section{Introduction}

Uneven economic growth has led to the emergence of urban poor, this affects meeting the needs of shelter so that the growth of slums in urban areas [1]. Slums are a phenomenon that characterizes cities in low to middle-income countries [2]. The phenomenon of slums is also happening in most cities in Indonesia [3]. Slums are a challenge in sustainable development, so a sustainable approach to handling is needed [4]. The successful upgrading of slums that can be sustainable needs to pay attention to the economic, social and environmental aspects to meet current and future needs $[4,5]$. These three aspects are

\footnotetext{
*Corresponding author: sunarti@pwk.undip.ac.id
} 
interconnected and require technological support, creativity, and innovation so that sustainable resettlement renovation activities can be achieved $[6,7]$.

The upgrading of slum settlements can be economically sustainable by taking into account that the residence of the population must be connected to the main employment center. In addition, housing must offer home-based economic activities that can open opportunities for the development of environmental economics (Gough et al. 2003; Wigle 2008 in [7]. The next element that is key to the upgrading of slums to be sustainable is the social dimension. In this case, the involvement of community-based organizations is important to support the formation of identity, social cohesion, empowerment and shared ownership [7, 8]. Slums cannot be made sustainable unless ecological themes are considered. Providing efficient and equitable sanitation, clean water, and having a welldesigned household waste management system from the collection, transportation, processing to recycling are important elements that contribute to sustainable housing $[4,7]$. Research that has never been done is how to model the linkages of environmental, social, and economic aspects after the renovation of settlements that have an impact on the sustainability of development and environmental preservation. This gap will be done by researchers compared with previous researchers.

While the Government of Indonesia in 2019 has sought a 100-0-100 program, namely $100 \%$ access to sanitation, $0 \%$ without slum, $100 \%$ access to clean water [9]. Various upgrading programs are carried out in the regions, one of them is in Demak Regency. Decree of the Regent of Demak Number: 475.26/319/2016 concerning the Determination of Slum Locations spread in Demak Sub-District, Sayung District, and Mranggen District. To implement settlements without slum, the government of Demak Regency succeeded in turning two slum villages into clean and healthy villages, one of which was Kalikondang Village, Demak District [10]. In 2018, the Desa Impian (Dream Village) of Kalikondang Village was also awarded as the winner of World Habitat Day at the level of Central Java Province. Based on this, researchers are interested in examining the results of upgrading in the village of Kalikondang, because the results of research conducted by researchers the previous year that successful slums will tend to experience slums again.

Based on the achievements of the upgrading slum in settlements of Kalikondang Village and the gap of previous research, this study will examine the model of the sustainability of development and management of settlements that have been arranged, so as not to cause slums again. Based on the gap between the previous research and the phenomena that occur in the field, the research objective is to find a sustainable model for settlement development and maintenance in Kalikondang Village, Demak Regency.

\section{Methods}

The research method used in this study is the Mixed Method, which is a method carried out by combining two research methods at the same time [11]. These mixed methods usually use qualitative and quantitative methods in research activity, so that more valid, reliable, comprehensive, and objective data will be obtained [12]. The mixed-method chosen is the concurrent embedded model by combining quantitative and qualitative simultaneously, from data collection to analysis [11]. Primary data is the main data, while secondary data as support for the primary data research method [13]. With the outbreak of the COVID-19 pandemic, secondary data were collected through the Kalikondang Village website, KOTAKU (Cities Without Slum Program), BPS, online media, and the like. Whereas, primary data were obtained from interviews by phone, email, WhatsApp with several speakers, namely chief of RT (the division of territory in Indonesia under the Rukun Warga/RW), chief of RW (the division of territory in Indonesia under hamlet), Community Self-Reliance Agency (BKM), Department of Housing and Settlement of Demak Regency. 
Field observations are assisted by field surveyors namely BKM Kondangsari facilitators who live in the RW next to the research location and the researchers make observations when the COVID-19 pandemic has not yet occurred.

The quantitative data of this study are data about the types of upgrading program activities, while qualitative data are the role of stakeholders and the impact of development and the form of maintenance activities that the community is now doing. While the analysis technique used is quantitative and qualitative descriptive which combines and compares the existing conditions with literature or other cases. This analysis technique is following [14] that for qualitative data can be used by analyzing the results of interviews, while for quantitative data analyzing from previous case studies.

\section{Result and Discussion}

\subsection{General Description of Study Area}

Kalikondang Village is one of the villages in Demak District, Demak Regency, which is located $+6 \mathrm{~km}$ from the city. Administratively it consists of 4 hamlets, $6 \mathrm{RW}$ and $37 \mathrm{RT}$, with an area of 335,489 hectares [15]. The total population of Kalikondang Village is 6,466 people. The location of slums in the village of Kalikondang covering an area of 16.81 hectares located in RW 04 RT 01 to 05 , RW 05 in RT 03, and RW 06 in RT 03. The prioritization of slum settlements is RW 04 because it is an isolated village, citizen actively participating and its location is located at the gateway of the urban center of Demak as the face of the city. RW 04, which consists of 5 RTs, is the focus of the research.

The area of the study site is 12.6 hectares $(3.76 \%)$ of the total area of Kalikondang Village. The total population of RW 04 is 768 people, 212 households. The number of buildings is 194 units with irregular conditions as many as 25 units and 78 units are not suitable for habitation. The majority of the population works as casual daily laborers. Another term for RW 04 is Dukuh Duduk because the majority of citizens defecate by squatting in any place (the river). Also, this village lacks infrastructure, and access to the village is difficult because the road is narrow and still made of land and drainage is not well connected.

\subsection{Slum Upgrading Program in Kalikondang Village}

The upgrading program in Kalikondang Village is carried out with a collaborative approach between the government, KOTAKU (Cities Without Slum Program), The Jateng Bank, People of Indonesia Bank (commonly known as BRI), Regional Government Budget (APBD), TMMD from Indonesian Army, Community self-help groups (KSM), Own Source Revenue (PAD), and community empowerment. The upgrading activity begins with the socialization and guidance to the community about the importance of a clean lifestyle, keeping the environment clean and maintained. Physically the activities start from 2017 to 2019, while the upgrading activities will be carried out to handle slums in RW 04 consisting of 5 RTs as shown in Table 1. The upgrading activities of slums in RT 01 to RT 05 RW 04 Dukuh Duduk, Kalikondang Village, Demak Regency before and after upgrading can be seen in the following Figure 1. 
Table 1. The Upgrading Activities in Slum Area RW 04 Kalikondang Village [16]

\begin{tabular}{|c|c|c|c|c|}
\hline No & Activities & Location & Volume & $\begin{array}{c}\text { Year of Development and } \\
\text { Source Fund }\end{array}$ \\
\hline 1 & Road Construction & $\begin{array}{l}\text { RT 002, } \\
003,004\end{array}$ & 815 meters & $\begin{array}{c}2017-2019 \\
\text { KOTAKU (Cities Without Slum } \\
\text { Program), Community } \\
\text { Empowerment }\end{array}$ \\
\hline 2 & Drainage Construction & $\begin{array}{l}\text { RT 002, } \\
003,004\end{array}$ & 815 meters & $\begin{array}{c}2017-2019 \\
\text { KOTAKU (Cities Without Slum } \\
\text { Program), Regional Governmen } \\
\text { Budget (APBD) }\end{array}$ \\
\hline 3 & Bridge Construction & RT 003, 004 & 2 units & $\begin{array}{c}\text { KOTAKU (Cities Without Slum } \\
\text { Program), Regional Governmen } \\
\text { Budget (APBD) }\end{array}$ \\
\hline 4 & $\begin{array}{l}\text { Renovation Un- } \\
\text { inhabitable Housing }\end{array}$ & $\begin{array}{l}\text { RT 002, } \\
003,004\end{array}$ & 52 units & $\begin{array}{c}2017-2019 \\
\text { KOTAKU (Cities Without Slum } \\
\text { Program), TMMD from } \\
\text { Indonesian Army, CSR Banking }\end{array}$ \\
\hline 5 & Build a Park & $\begin{array}{l}\text { RT 002, } \\
003,004\end{array}$ & 1 unit & $\begin{array}{c}2018 \text { - } 2019 \\
\text { Own Source Revenue (PAD), } \\
\text { Community Empowerment }\end{array}$ \\
\hline 6 & $\begin{array}{l}\text { Physical Houses } \\
\text { Alteration for Road } \\
\text { Construction }\end{array}$ & RT 001, 003 & 11 units & $\begin{array}{c}2017-2019 \\
\text { KOTAKU (Cities Without Slum } \\
\text { Program), Community } \\
\text { Empowerment }\end{array}$ \\
\hline
\end{tabular}

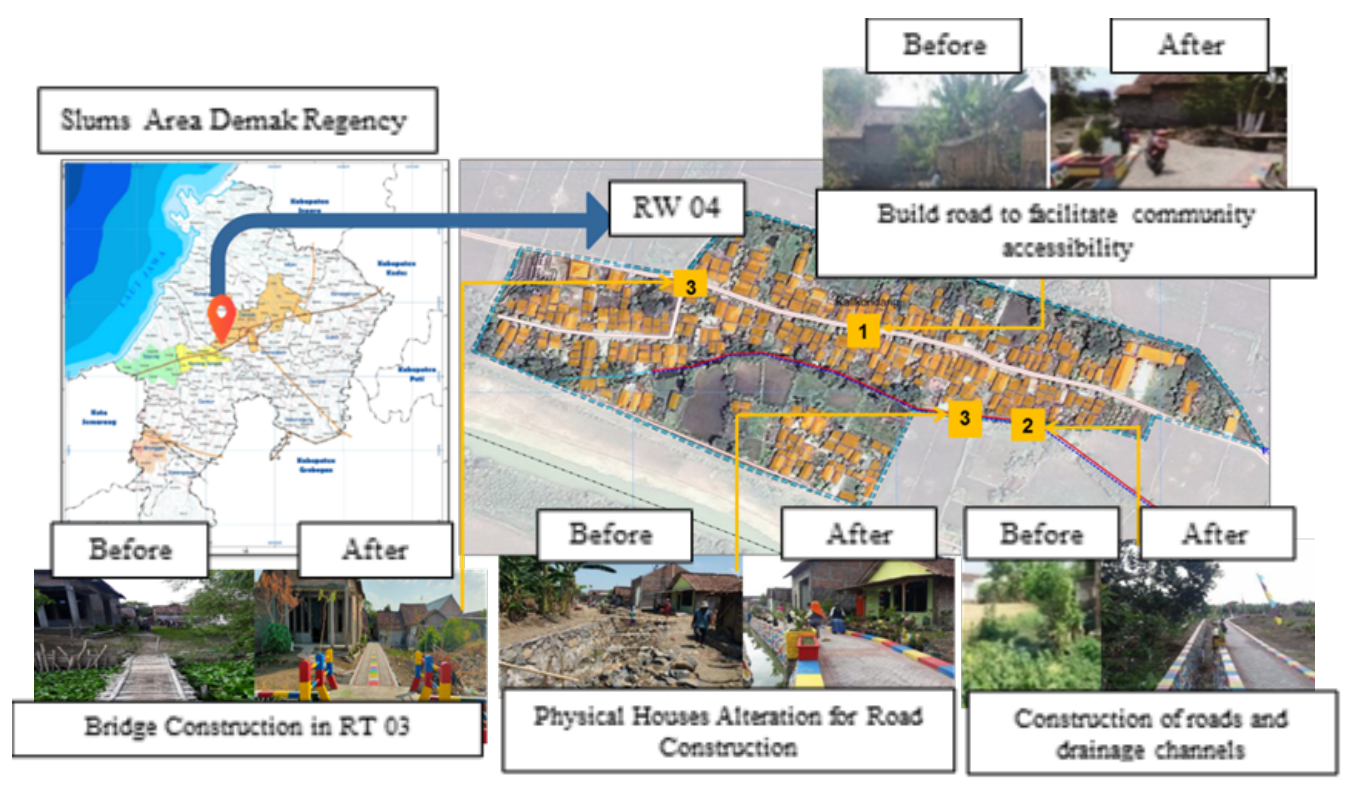

Figure 1. Infrastructure Upgrading Has Been Carried Out in RW 04 Kalikondang Village [17]

In addition to physical development, some training for environmental maintenance, and community capacity building are training on home industry, hydroponics and plant nurseries, waste management and capital loans. After the slum upgrading program, RW04 began to have some improvements in terms of social, economic, and environmental aspects. RW 04 becomes the dream village of healthy, clean, comfortable, and neatly arranged 
citizens. Some of the activities that have been carried out are greening, waste management activities, the application of livelihood and organization. Even now Dukuh Duduk RW 04 Kalikondang Village is a model for other villages.

The results of the upgrading of slums in RW 04 by opening and repairing the road to Dukuh Duduk makes it easy for the community to access and [18] affect regional development of RW 04. This has led to the emergence of new businesses, namely the emergence of the small kiosk, street vendors selling at the edge of the new road, and in the park. Business citizens who have prospects and still survive are tire businesses, 3 households have tire businesses (motorcycle tires, car tires, and 3-wheeled tires). Besides, there is also a business of making plants pots from used tires. As for the Open Space in the form of a park that gave rise to street vendors, the majority of traders are citizens of RW 04 . New economic activities after the renovation can be seen in Figure 2.

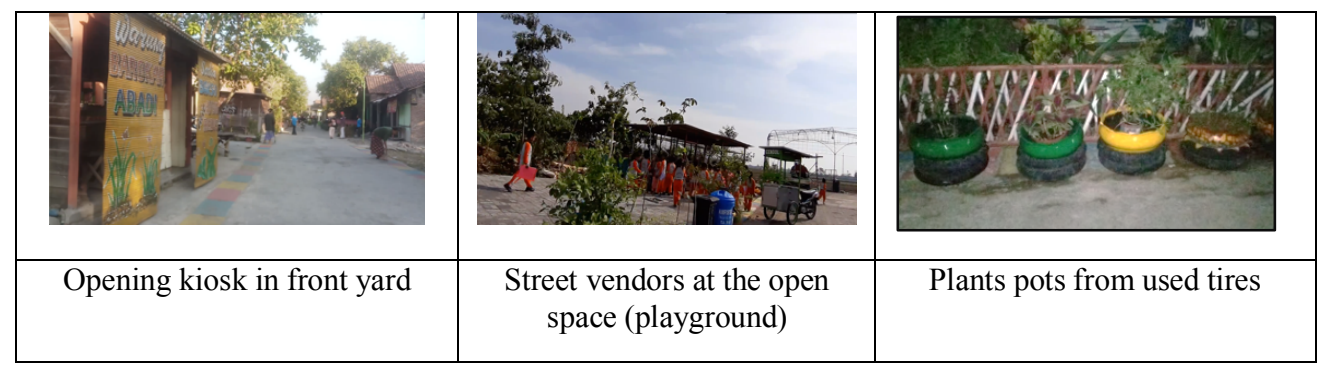

Figure 2. Activities and New Business After The Upgrading in RW 04 Kalikondang Village [17]

The efforts after this upgrading have caused changes in people's behavior to live clean and healthy lives as well as changes in livelihoods and increased incomes. The emergence of businesses that can increase income can have an impact on the sustainability of the development and maintenance of the citizens' environment in RW 04, Kalikondang Village. This is consistent with the results of the interview with the following informant:

The economic impact is very influential, the emergence of small kiosks that did not exist previously, and the emergence of access roads that now exist so that people can pass ... (Head of $R W$ 04)

The economic impact with the creation of a new park and the presence of visitors from outside the Kalikondang Village who come and automatically the citizens' economy increases due to trading ... (Head of RT 04/RW 04)

\subsection{The Sustainability Without Slum in Kalikondang Village}

The upgrading of the development of Kalikondang Village which has become the dream of RW 04 citizens has been realized, it is hoped that development can continue for all aspects in terms of physical, social and economic aspects. Sustainability of the economic aspect is the impact of upgrading on physical development, namely the opening of access roads along the 815 meters followed by a drainage network leading to the location of Kalikondang Village. The construction of 2 bridges also opened access between RTs in RW 04. The new road that is connected to other RTs and RWs is used by citizens for several activities including learning for outdoor PAUD children and a gathering place for people to socialize, as well as PKK (Empowerment of Family Welfare) ladies' gymnastics. The opening of a new park is equipped with a mini zoo as a visit to school children. Some of these activities emerged after the renovation of the settlement made the opening of kiosks and street vendors at the place where the new activity took place. In addition to the opening of the kiosk, there is a business in making plants pots from used tires. This effort causes the income of citizens to increase slightly and has an indirect impact to be used to care for their 
environment. This is consistent with the opinion of researchers, that the sustainability of settlement development activities can be successful by improving social, economic, and environmental aspects $[4,5]$ which are interconnected and require technological support, creativity, and innovation $[6,7]$. The upgrading of RW 04 has had a positive impact on society, namely the maintenance and development of the environment and the community. In terms of maintenance and development, funds or budgets are needed to maintain the environment without slum [4]. To get funds can be done by increasing the business of citizens who have begun to emerge and managed together professionally.

The impact of physical development is not only an increased economic aspect but is followed by social aspects. Institutions that have already been formed in the community can have the potential to manage the business and need support, collaboration with other stakeholders. The institutions that have the potential to be able to manage in a participatory manner are Youth Organization, PKK at the RT or RW level, and other associations.

Community institutions can collaborate with local governments starting from the lowest level at the village, sub-district, and district levels as well as with entrepreneurs. The type of collaboration is to increase organizational capacity, capital loans, increase the type of business or production, quality, and marketing. In addition to achieving sustainable development, it is necessary to pay attention to providing space for street vendors in public spaces. Through marketing can increase business productivity, so employers need workers so that production can reach the target demand.

The relationship between the social community that is packaged in an institution to improve the economy of citizens is very closely related. Thus developing businesses can help to open up employment opportunities for RW 04 citizens who are predominantly employed as laborers. The emergence of embryos of new forms of business due to the upgrading of slums can improve the economy of citizens, and have an impact on the sustainability of development and maintenance of their settlements. The relationship between economic aspects, social aspects, and environmental aspects of sustainable development without slum as shown in Figure 3. The RW 04 settlement sustainability model is a model of new economic resources that develop after the upgrading of slums.

Settlement model of the RW 04 is originated from a new economic source that develops after the upgrading that is related to the socio-economic aspects of society and impacts on sustainability for environmental maintenance and development. This new economic resource is important for the continued maintenance and development of RW 04 Kalikondang Village.

During this period, there were obstacles in the sustainability of settlement maintenance, namely the COVID-19 outbreak. The existence of this pandemic has affected the community activities of RW 04, which previously used to be a regular gathering, but it has rarely been done, besides reducing the income level of the majority of informal workers. This has resulted in the quality of the environment not being maintained and feared could decline, because maintenance activities can be sustainable if there is cooperation with other stakeholders to improve the economic, social, and environmental. 


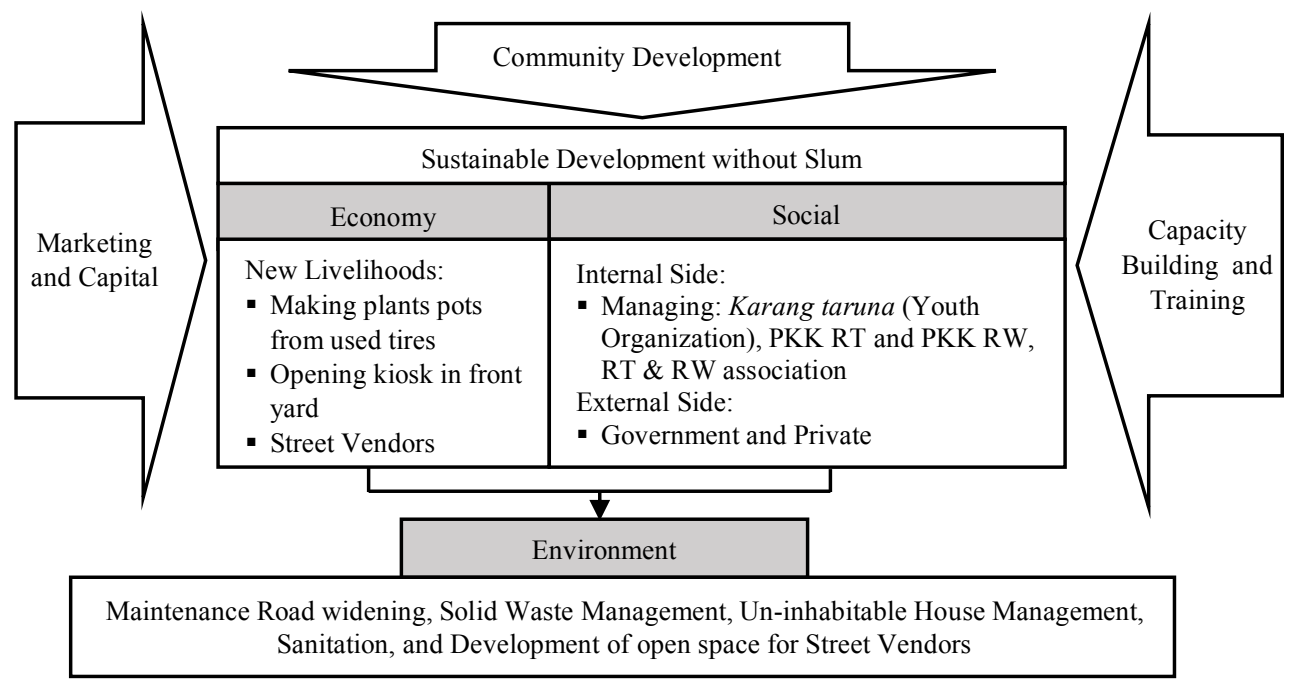

Source: Researcher Analysis, 2020

Figure 3. Diagram of The Relationship Between Economic, Social and Environmental Aspects of The Sustainable Development of RW 04 Kalikondang Village

\subsection{The Role of Stakeholders for Sustainable Development Environment in Kalikondang Village}

Sustainability for the maintenance and construction of settlements in Kalikondang Village requires stakeholder collaboration. Forms of collaboration can implement communitybased and functionally-based strategies [19]. A community-based strategy is shown by the people who fully participate from the initial stage to the end of the development process. Whereas the functionally-based application focuses on the assistance and supervision of the village government and the community organization BKM Kondangsari. In this case, the related party must be interactive, [20] is participation by directing the planning of strengthening community institutions that already exist. Environmental governance needs to consider ways that all communities can access existing resources and how these groups can participate in environmental management [21]. The members of the participation in RW 04 such as PKK RT, PKK RW, Karang taruna (Youth organization) RT, and RW because these institutions are the lowest institutions to be able to realize the sustainable development and maintenance of the settlement. This is consistent with previous researchers that the institutions at the lowest level that exist in the community to be able to maintain the environment sustainably are at the RT level [22]. Figure 4 shows the role of stakeholders for sustainable development without a slum. 


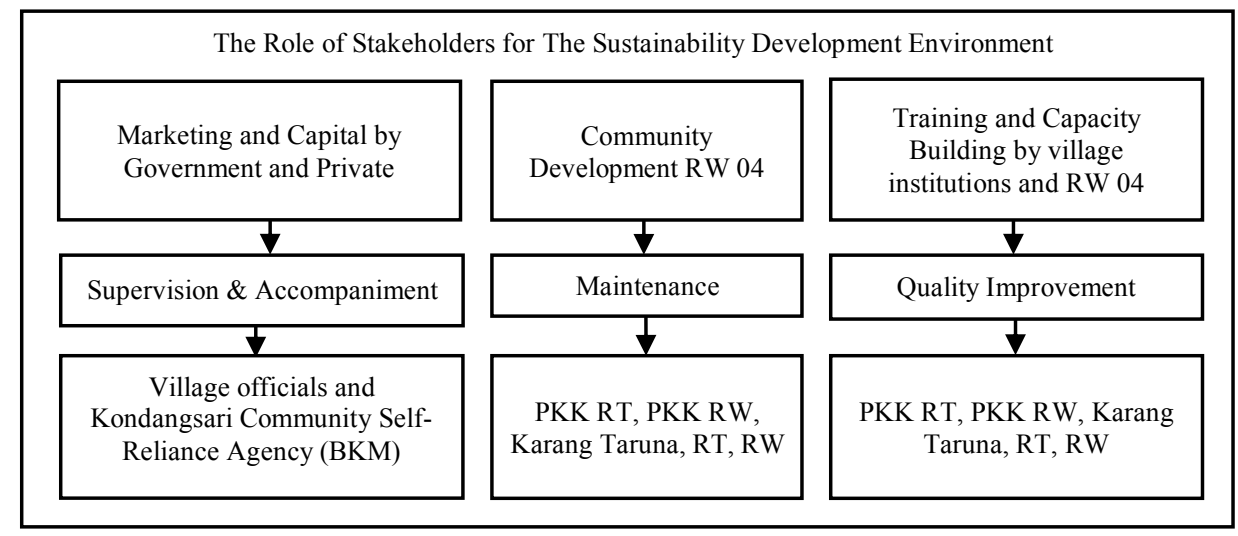

Source: Researcher Analysis, 2020

Figure 4. The Role of Stakeholders in The Sustainable Development of Kalikondang Village

In the continuation development of the settlements won't return to slums, collaboration with stakeholders, and the community itself is needed to maintain a clean, healthy, comfortable and neatly arranged environment.

\section{Conclusion}

This model of settlement development sustainability comes from new economic sources that are united with the existence of a community institution for environmental maintenance and development. The contribution of the theory of sustainability housing from the beginning of the new economy after the arrangement, while the previous sustainability housing only analyzes the existing economy, is different from the current study that the new economic source of the results of the arrangement of the environment. This is evidenced by the business of making plants pots from used tires, the emergence of kiosks in front yard, and the emergence of street vendors around an open space. The existence of a park that is the object of a study visit for students to know about caring for a clean environment so that the street vendors emerge. From some of these potentials little by little can help income RW 04 which then gets funds or budgets with community institutions as fund managers allocated for the maintenance and development of RW 04 settlement environment. The results of this study also contribute to policies in managing the citizens' environment after upgrading to be sustainable.

\section{Acknowledgement}

This research was financially supported by the Faculty of Engineering of Universitas Diponegoro, Indonesia through the 2020 Strategic Research Grant with a letter of assignment to conduct research numbers: 2496 / SPWK07 /UN7.5.3.2/PP/2020. In addition, the authors also thank Kharunia Putri, S.PWK for assisting in the research process.

\section{References}

1. Hariyanto, A. Strategi Penanganan Kawasan Kumuh Sebagai Upaya Menciptakan Lingkungan Perumahan Dan Permukiman Yang Sehat (Contoh Kasus: Kota Pangkalpinang). J. Perenc. Wil. dan Kota UNISBA 7, 11-37 (2007). 
2. Ezeh, A. et al. The history, geography, and sociology of slums and the health problems of people who live in slums. Lancet 389, 547-558 (2017).

3. Santi, Bachrun, R. \& Ornam, K. Typology of Slum Management in Coastal Settlement as a Reference of Neighborhood Planning in Konawe. J. Phys. Conf. Ser. 846, (2017).

4. UN Habitat. Sustainable Housing for Sustainable Cities: A Policy Framework for Developing Countries. (United Nation Human Settlements Programme, 2012).

5. Oyebanji, A. O., Liyanage, C. \& Akintoye, A. Critical Success Factors (CSFs) for achieving sustainable social housing (SSH). Int. J. Sustain. Built Environ. 6, 216227 (2017).

6. Moulaert, F. et al. Social innovation in an unsustainable world. The International Handbook on Social Innovation vol. 66 (2013).

7. Smets, P. \& van Lindert, P. Sustainable housing and the urban poor. Int. J. Urban Sustain. Dev. 8, 1-9 (2016).

8. Sunarti, S., Syahbana, J. A. \& Manaf, A. Space transformation in a low-income housing community in Danukusuman, Surakarta. Int. J. Hous. Mark. Anal. 12, 265280 (2019).

9. Sari, J. 'Kotaku' Berdayakan Masyarakat Sulap Kawasan Kumuh Menjadi Bersih Tertata.https://www.wawasan.co/news/detail/8368/kotaku-berdayakan-masyarakatsulap-kawasan-kumuh-menjadi-bersih-tertata (2019).

10. Suara Merdeka. Pemda Jamin Demak Bebas Kumuh 2021. SuaraMerdeka.com (2019).

11. Creswell, J. W. Controversies in mixed methods research. (The Sage handbook of qualitative research, 2011).

12. Sugiyono. Metode Penelitian Kuantitatif, Kualitatif dan R\&D. (Alfabeta, 2011).

13. Creswell, J. Research Design Pendekatan Kualitatif, Kuantitatif, dan Mixed. (Pustaka Pelajar Yogyakarta, 2009).

14. Yin, R. K. Case Study Research: Design and Methods (Fourth Edition). in Evaluation \& Research in Education (Sage Publisher, 2009).

15. Badan Pusat Statistik. Kecamatan Demak Dalam Angka 2019. (Badan Pusat Statistik Kabupaten Demak, 2019).

16. Cities Without Slum Program. Dokumen Publikasi Program KOTAKU Desa Kalikondang Kabupaten Demak Tahun 2019. (2019).

17. Cities Without Slum Program. Best Practice Kegiatan KOTAKU Kabupaten Demak 2017-2019. (2019).

18. Dewi, A. P., Sunarti, S. Keberadaan Permukiman Kumuh Tambak Lorok Kota Semarang terhadap Pengembangan Kampung Wisata Bahari. 8, 1-11 (2019).

19. Schubeler, P. Participation and Partnership in Urban Infrastructure Management. (The World Bank, 1996).

20. Hanif, N. Pertumbuhan \& Penyelenggaraan Pemerintahan Desa. (Erlangga, 2011).

21. Evans, J. P. Environmental governance. Environmental Governance vol. 4 (Elsevier, 2012).

22. Yuliastuti, N., Wahyono, H., Syafrudin, S. \& Sariffuddin, S. Dimensions of community and local institutions' support: Towards an eco-village Kelurahan in Indonesia. Sustain. 9, (2017). 